\title{
Should an Appendectomy Be Performed for the Treatment of Amyand's Hernia with Non-Inflamed Vermiform Appendix? A Case Report and Review of the Literature
}

\author{
Serdar Kuru Abdullah Bulgurcu Kemal Kismet Ertugrul Ertas \\ General Surgery Department, Ankara Training and Research Hospital, Ulucanlar, Ankara, Turkey
}

Keywords

Amyand's hernia $\cdot$ Inguinal hernia $\cdot$ Appendectomy $\cdot$ Hernia sac

\section{Summary}

Background: Presence of vermiform appendix in an inguinal hernia, whether inflamed or not, is called Amyand's hernia. We present a case that was operated on for Amyand's hernia and discuss whether or not an appendectomy should be performed in such a patient, even in the case of a non-inflamed appendix. Case Report: We report a case of Amyand's hernia with noninflamed appendix, adhering to the inguinal sac wall. A 36-yearold man who was scheduled for elective surgery was referred to our hospital for a large right-side inguinal hernia. During the operation, the appendix was found within the indirect sliding hernia sac. The appendix was non-inflamed and adhered to the inguinal sac wall. The appendix and cecum were freed from adhesions to the sac. Then, appendectomy was performed. The hernioplasty was carried out with synthetic mesh. The postoperative course of the patient was uneventful while pathological examination revealed a normal appendix with lymphoid hyperplasia. The patient had no problems on the postoperative follow-ups after 3 and 6 months. Conclusions: The treatment approach of Amyand's hernia depends on the inflammatory state of the appendix. If the appendix is inflamed, appendectomy is mandatory. If the appendix is normal, appendectomy is controversial. Although there is a general consensus by most authors that a normal appendix in the hernia sac does not require appendectomy because of the risk of infectious complications, it is important to be aware of all clinical settings. The decision to perform an appendectomy and/or to use the mesh technique should always be individualized to the patient.
Schlüsselwörter

Amyand-Hernie $\cdot$ Leistenhernie $\cdot$ Appendektomie $\cdot$ Herniensack

\section{Zusammenfassung}

Hintergrund: Die Präsenz des Appendix - ob entzündet oder nicht - innerhalb eines Leistenbruchs wird Amyand-Hernie genannt. Wir stellen einen Fall vor, in dessen Rahmen der Patient aufgrund einer Amyand-Hernie operiert wurde, und diskutieren, ob eine Appendektomie - auch bei nichtentzündetem Appendix - bei einem solchen Patienten durchgeführt werden sollte. Fallbericht: Im Folgenden beschreiben wir den Fall eines Patienten mit einer Amyand-Hernie und einem nichtentzündeten Appendix, der an der Wand des Herniensacks haftete. Der 36-jährige Mann, der für eine elektive Operation vorgesehen war, wurde aufgrund einer großen rechtsseitigen Leistenhernie an unser Krankenhaus überwiesen. Während der Operation wurde der Appendix im indirekten gleitenden Herniensack aufgefunden. Der Appendix war nicht entzündet und haftete an der Wand der Leistenhernie. Die Adhäsionen von Appendix und Zökum an den Herniensack wurden gelöst. Daraufhin wurde eine Appendektomie durchgeführt. Die Hernioplastik wurde mithilfe eines synthetischen Netzgewebes durchgeführt. Der postoperative Verlauf des Patienten war unauffällig, während die pathologische Untersuchung einen normalen Appendix mit einer lymphoiden Hyperplasie aufzeigte. Der Patient war im Rahmen der postoperativen Nachuntersuchungen nach 3 sowie nach 6 Monaten unauffällig. Schlussfolgerungen: Der Behandlungsansatz bei einer Amyand-Hernie hängt vom Entzündungszustand des Appendix ab. Wenn der Appendix entzündet ist, ist eine Appendektomie zwingend. Ist der Appendix jedoch nicht entzündet, wird die Appendektomie kontrovers diskutiert. Obwohl die meisten Autoren von einer Appendektomie abraten, um eine Kontamination zu vermeiden, ist es hier wichtig, alle klinischen Begleitumstände zu berücksichtigen. Die Entscheidung, eine Appendektomie durchzuführen und/oder eine Netztechnik einzusetzen, sollte sich daher immer an den individuellen Gegebenheiten des Patienten orientieren.

\section{KARGER \\ Fax +497614520714 \\ Information@Karger.com}

www.karger.com (c) 2013 S. Karger GmbH, Freiburg

$1662-6664 / 13 / 0291-0051 \$ 38.00 / 0$

Accessible online at:

www.karger.com/vim
Dr. Serdar Kuru

Genel Cerrahi Klinigi

S.B. Ankara Egitim ve Arastirma Hastanes

Ulucanlar, Ankara, 06340, Turkey

dokserkur@yahoo.com.tr 


\section{Introduction}

The finding of a vermiform appendix in the case of an inguinal hernia is called Amyand's hernia. This unusual situation is estimated to occur in approximately $1 \%$ of adult inguinal hernia cases. Amyand's hernia complicated by acute appendicitis is much less common. The inflammatory status of the vermiform appendix determines the surgical approach and the type of hernia repair. If the appendix is inflamed, appendectomy is mandatory. If the appendix is not inflamed, appendectomy is not recommended in order to avoid contamination of a clean hernia repair wound; as a result, this approach is controversial. The aim of this report is to discuss whether or not an appendectomy should be performed in a patient with Amyand's hernia including the event of a non-inflamed appendix.

\section{Case Report}

A 36-year-old man scheduled for elective surgery was referred to our hospital for a large right-side inguinal hernia. Laboratory data were within normal limits. The patient had no accompanying significant disease. The oblique conventional incision between the external and internal rings was used to achieve a better approach. After opening the hernia sac, the appendix was found within the indirect sliding hernia sac (fig. 1). The distal portion of the appendix was attached to the distal portion of the hernia sac, which lay outside the external ring of the right groin. The appendix was non-inflamed and adhered to the inguinal sac wall (fig. 2), and the cecum was pulled up to the internal inguinal orifice by the adhered appendix. The appendix and cecum were freed from adhesions to the sac. Appendectomy was performed. The cecum was placed back into the abdominal cavity. The hernia neck was closed with suture ligation, and the hernia sac was excised. Herniorrhaphy was performed with synthetic mesh. The patient had an uneventful postoperative course, and no complications developed. He was discharged on the next day. Pathological examination revealed a normal appendix with lymphoid hyperplasia. The patient showed no problems on the follow-up examinations 3 and 6 months after the operation.

\section{Discussion}

The first appendectomy located in an inguinal hernia was performed by Claudius Amyand on December 6, 1735, at St George's Hospital, London. UK. The patient, Hanvil Anderson, was an 11-year-old boy with an inguinal hernia and a fecal fistula discharging in the groin. During the operation, the appendix was found to be in the hernia sac and the fistula was traced to a perforation of the appendix by a pin [1]. The case was reported in the Philosophical Transactions of the Royal Society in 1736 [2].

There are several clinical manifestations of Amyand's hernia: reducible or incarcerated hernia with non-inflamed or inflamed appendix and ingested foreign body, which may be metallic or non-metallic, in the appendix causing perforation or not. Nowadays, all these presentations of vermiform appendix within the inguinal hernia sac are called Amyand's

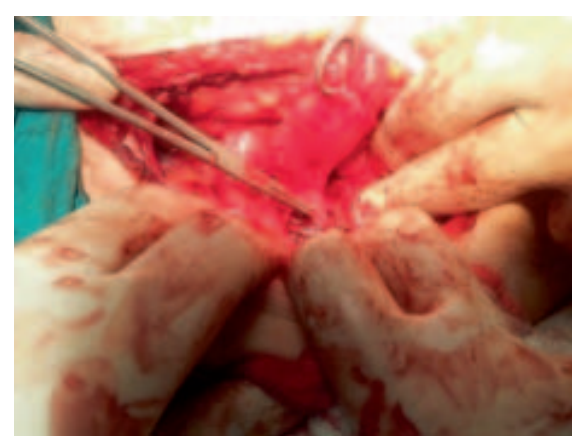

Fig. 1. Appendix found within the indirect sliding hernia sac.

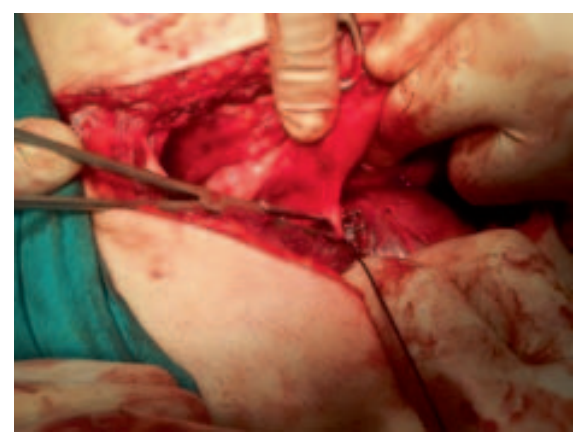

Fig. 2. Non-inflamed appendix adhering to the inguinal sac wall.

hernia [3]. The finding of a non-inflamed appendix within an inguinal hernia is estimated to be found in $1 \%$ of all inguinal hernia repairs [4]. In a series of 1,341 inguinal hernia operations, D'Alia et al. [5] reported the finding of appendicitis in the inguinal hernia with $0.08 \%$. Most reported cases of Amyand's hernia have been seen in the right inguinal region, and only a few reported cases have occurred in the left inguinal region $[6,7]$.

This entity should be differentiated from inguinal hernia with strangulation, Richter's hernia, or inguinal lymphadenitis. It remains a commonly encountered condition in the inguinal region, where the hernia sac may contain the omentum or small bowel. Unusual contents may be encountered, such as the bladder, a Meckel's diverticulum (Littré's hernia), or a portion of the wall of the intestine (Richter's hernia). In male patients, differential diagnosis should include bleeding testicular tumors or epididymitis [8].

Abu-Dalu and Urca [9] have suggested that the appendix becomes more vulnerable to trauma in Amyand's hernia and is ultimately retained by adhesions. Its blood supply may subsequently be cut off or significantly reduced, resulting in inflammation and bacterial overgrowth. Contraction of the abdominal muscles and other sudden increases in intraabdominal pressure may cause compression of the appendix, resulting in further inflammation [9]. The appendix becomes more vulnerable to microtraumas. Secondary to this, fibrosis develops, and the appendix becomes adhered to the hernia sac [8]. In our case, the distal portion of the appendix was attached to the distal portion of the hernia sac. The appendix was non-inflamed and adhered to the inguinal sac wall, and the cecum was pulled up to the internal inguinal orifice by the adhered appendix. 
Table 1. Treatment classification of Amyand's hernias described by Losanoff and Basson

\begin{tabular}{|c|c|c|}
\hline Classification & Description & Surgical management \\
\hline Type 1 & $\begin{array}{l}\text { Normal appendix within an } \\
\text { inguinal hernia }\end{array}$ & $\begin{array}{l}\text { Mesh repair, appendectomy in } \\
\text { young patients }\end{array}$ \\
\hline Type 2 & $\begin{array}{l}\text { Acute appendicitis within an } \\
\text { inguinal hernia, no abdominal } \\
\text { sepsis }\end{array}$ & $\begin{array}{l}\text { Appendectomy through hernia, } \\
\text { primary endogenous repair of hernia, } \\
\text { no mesh }\end{array}$ \\
\hline Type 3 & $\begin{array}{l}\text { Acute appendicitis within an } \\
\text { inguinal hernia, abdominal wall, } \\
\text { or peritoneal sepsis }\end{array}$ & $\begin{array}{l}\text { Laparotomy, appendectomy, } \\
\text { primary repair of hernia, no mesh }\end{array}$ \\
\hline Type 4 & $\begin{array}{l}\text { Acute appendicitis within an } \\
\text { inguinal hernia, related or } \\
\text { unrelated abdominal pathology }\end{array}$ & $\begin{array}{l}\text { Manage such as hernia types } 1-3 \text {, } \\
\text { investigate or treat second pathology } \\
\text { as appropriate }\end{array}$ \\
\hline
\end{tabular}

Amyand's hernia is difficult to diagnose clinically and is rarely diagnosed preoperatively. Weber [10] was the only surgeon who made the correct diagnosis preoperatively. In his review of 60 cases over a 12-year period, only one case was diagnosed preoperatively. Amyand's hernia is a rare condition that has been frequently diagnosed accidentally during a hernioplasty or in the emergency room, especially in the case of incarcerated inguinal hernia. Our patient underwent elective surgery for herniorrhaphy and did not show signs or symptoms suggesting a complicated inguinal hernia. As a result, we were only able to make the diagnosis intraoperatively.

The difficulty in diagnosis has its origins in the considerable variation of symptoms that patients present with, depending on whether the appendix is normal, incarcerated, or perforated. The most common symptom on presentation is painful inguinal or inguinoscrotal swelling, while the history and examination usually point to an incarcerated hernia [11]. Fever and leukocytosis are inconsistent findings. Ultrasound often demonstrates a potentially inflammatory mass within the hernia sac. Due to the physical condition of the patient, the diagnosis of a strangulated hernia is often made [8]. Computed tomography scans may be useful in diagnosis, but are typically not performed routinely. Diagnosis is made by the demonstration of an inguinal hernia containing a blind-ending tubular structure with thickened walls, which is in contact with the cecum. Magnetic resonance imaging is most useful for visualizing the appendix and demonstrating its relationship with the surrounding structures. It aids in confidently making the right diagnosis preoperatively, enabling the surgeon to successfully combine both appendectomy and hernia repair [8].

Another issue is whether an appendectomy needs to be performed at all. Losanoff and Basson have distinguished four basic types of Amyand's hernia which should be treated differently (table 1) [12-14]. The inflammatory status of the vermiform appendix determines the surgical approach and the type of hernia repair. All surgeons agree that the repair of the hernia should be performed according to the Bassini or Shouldice techniques if appendicitis exists, although without using synthetic meshes or plugs within the defect due to the high risk of suppuration of such material. In the case of a nor- mal appendix, incidentally found within the hernia sac, the performance of a prophylactic appendectomy along with the hernia repair is not favored by many authors. Appendectomy adds the risk of infection to an otherwise clean procedure. Superficial wound infection increases morbidity, and deep infection may contribute to hernia recurrence. There are some authors who recommend a reduction of the appendix into the abdomen as well as mesh hernioplasty if there is no acute appendicitis, and appendectomy followed by hernia repair if an inflamed appendix is found. Appendectomy via hernia sac is hardly to be justified, especially in the case of mesh being implanted. Therefore, two alternatives should be discussed: i) To split the operation, i.e. first complete the reduction of hernia sac and mesh repair without any contamination and afterwards conduct an appendectomy by a separate incision, and ii) to carry out a laparoscopic hernia repair and to perform a laparoscopic appendectomy after mesh insertion and closure of peritoneum. Although these general rules are certainly acceptable, there are more clinical scenarios to keep in mind. Correspondingly, there should be a critical appraisal of the treatment classification done by Losanoff and Basson. Since the appendix was non-inflamed in our case, we preferred mesh repair after appendectomy. This procedure is compatible with classification type 1 of Losanoff and Basson (description: normal appendix within an inguinal hernia; surgical management: mesh repair, appendectomy in young patients) (table 1).

A long appendix which stretches the cecum may cause chronic pain if left behind. Manipulations to detach and reduce the appendix in the abdomen may stimulate the inflammatory process [14]. Furthermore, consideration of appendectomy in young patients must take the size of the hernia into account since prosthetic material is contraindicated; however, large hernias are more likely to recur if repaired using only the patients' own tissue [14]. In our case, the hernia mass was located in the scrotum, and the appendix of the patient was non-inflamed and adhered to the inguinal sac wall, while the cecum was pulled up to the internal inguinal orifice by the adhered appendix. For that reason, we performed an appendectomy, and the hernia was repaired using synthetic mesh. 


\section{Conclusion}

Amyand's hernia is a rare condition that is frequently diagnosed accidentally during a herniorrhaphy. The treatment approach depends on the inflammatory state of the appendix. If the appendix is normal, appendectomy is controversial. Although there is a general consensus by most authors that a normal appendix in the hernia sac does not require appendec- tomy because of the risk of infectious complications, it is important to be aware of all clinical settings, and the decision to perform an appendectomy and/or use the mesh technique should always be individualized to the patient.

\section{Disclosure Statement}

The authors have no conflict of interest.

\section{References}

1 Hutchinson R: Amyand's hernia. J Royal Soc Med 1993;86:104-105.

2 Amyand C: Of an inguinal rupture, with a pin in the appendix caeci incrusted with stone; and some observations on wounds in the guts. Phil Trans R Soc Lond 1736;39:329-342.

3 Llullaku SS, Hyseni NS, Kelmendi BZ, et al.: A pin in appendix within Amyand's hernia in a six-yearsold boy: case report and review of literature. World J Emerg Surg 2010;5:14.

4 Thomas WE, Vowles KD, Williamson RC: Appen dicitis in external herniae. Ann R Coll Surg Engl 1982;64:121-122.

5 D'Alia C, Lo Schiavo MG, Tonante A, et al.: Amyand's hernia: case report and review of the literature. Hernia 2003;7:89-91.
Gupta S, Sharma R, Kaushik R: Left-sided Amyand's hernia. Singapore Med J 2005;46:424-425.

7 Johari HG, Paydar S, Davani SZN, et al.: Leftsided Amyand hernia. Ann Saudi Med 2009;29: 321-322.

8 Laermans S, Aerts P, De Man R: Amyand's hernia: inguinal hernia with acute appendicitis. JBR-BTR 2007;90:524-525.

9 Abu-Dalu J, Urca I: Incarcerated inguinal hernia with a perforated appendix and periappendicular abscess: report of a case. Dis Colon Rectum 1972; 15:464-465.

10 Weber RV, Hunt ZC, Kral JG: Amyand's hernia: etiologic and therapeutic implications of two complications. Surg Rounds 1999;22:552-556.
11 Flood L, Chang KH, McAnena OJ: A rare case of Amyand's hernia presenting as an enterocutaneous fistula. J Surg Case Rep 2010;7:6.

12 Losanoff JE, Basson MD: Amyand hernia: what lies beneath - a proposed classification scheme to determine management. Am Surg 2007;73:12881290.

13 Losanoff JE, Basson MD: Amyand hernia: a classification to improve management. Hernia 2008;12: 325-326.

14 Psarras K, Lalountas M, Baltatzis M, et al.: Amyand's hernia - a vermiform appendix presenting in an inguinal hernia: a case series. J Med Case Rep 2011;5:463 